\title{
COURSERA ONLINE COURSE: A PLATFORM FOR ENGLISH TEACHERS' MEANINGFUL AND VIBRANT PROFESSIONAL DEVELOPMENT
}

\author{
Arnis Silvia \\ (arnis@uinjkt.ac.id) \\ UIN Syarif Hidayatullah Jakarta \\ Jl. Ir. H. Juanda No.95 Ciputat
}

\begin{abstract}
This article reports on English teachers' attitudes towards a professional development program run by Coursera (coursera.org). These teachers were participants of Foundation of Teaching for Learning 1: Introduction online course. Using a survey case study, the findings reveal that most of the participants perceive the course as a well-organized and effective platform to engage in professional learning. Coursera is an online learning platform offering various courses for teacher educators which are meaningful (closely related to their daily teaching practice) and vibrant (involves active collaboration among peer participants to review and assess their projects). Albeit this nature, another finding shows that the participants lament that their institutions do not provide professional development (PD) support. In fact, PD programs are not constrained to faceto-face encounters, since it can be designed using online platforms such as Coursera, a massive open online course (MOOC). Accordingly, the contribution of the article is to show how online platforms make meaningful and vibrant teacher professional development (TPD) possible. The implication of the study is that school administrators and policy makers should provide support for their teachers to take online PD programs. This professional learning should contribute to the best teaching practice and student learning attainment.
\end{abstract}

Keywords: English teachers, MOOCs, online professional development, teacher professional learning

DOI: http://dx.doi.org/10.15639/teflinjournal.v26i2/228-246 
In the context of English language pedagogy (ELP), English teachers are facing a challenge to foster their professional development; while at the same time, they are occupied by administrative work at school, initiatives to improve students ' abilities, and growing needs for bringing themselves up-todate with the literature on ELP. These demands require English teachers to juggle different roles as teacher administrators, language course designers, curriculum implementers, evaluators, and professional learners.

Many countries have invested heavily in TPD activities. This investment plays a crucial role in ensuring quality pedagogical practice, which should have significant implications for both teacher professional learning and student learning. In short, this millennium has witnessed the fact that TPD is clearly an important dimension of enhancing education through improving the quality and expertise of teachers or educators. This recognizes interconnectedness between quality and vibrant TPD and student learning performance. More crucially, professional teachers should engage in such TPD programs so that they can see themselves as life-long learners who own a sustained passion for developing their professionalism and for making innovation and changes in their own classroom practices.

PD programs are a systematic and concerted effort to bring about innovation and changes in classroom practices of teachers, their attitudes and beliefs, and learning outcomes of students (Guskey, 2002). He then proposes a model of teacher change as the upshot of teachers' PD programs as seen in Figure 1.

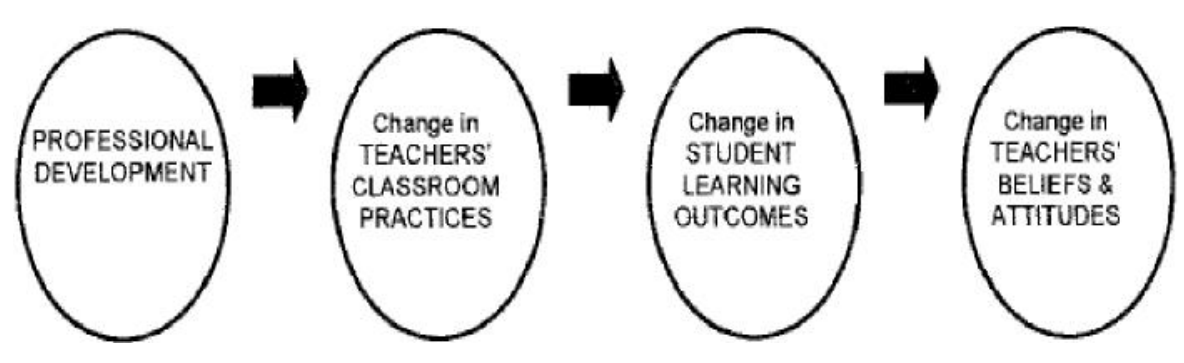

Figure 1: A Model of Teacher Change (Guskey, 2002, p. 383)

This model suggests a different sequence among the three major outcomes of professional development. This model shows that PD enables teachers to make a fundamental change in their pedagogic practice so that it has implica- 
tions for students' learning outcomes. Finally, teachers' attitudes and beliefs change after they gain evidence of improvement in student learning performance. This model also emphasizes that TPD is an incremental process of professional learning involving concerted effort, time, energy, and opportunities. This process helps teachers reflect on their TPD journeys, and in turn, this reflective encounter assists them to become reflective practitioners and researchers. Anchored in this informed reflection, teachers are motivated to make innovation and changes in their own pedagogic territories.

Ideally, an effective PD program works flexibly around teachers' busy schedules, provides sustained follow-up PD activities, includes ongoing coaching, engages teachers in active learning experiences with teaching methods, focuses on integration with specific subject-matter content, involves reflection on instruction and beliefs, fosters collaboration with colleagues, and examines the impact of instruction on student outcomes (Jaquith, Mindich, Wei, \& DarlingHammond, 2011; Ross, 2011). There has been a plethora of face-to-face workshops, training, and short courses geared to engage teachers in TPD, but in reality, there is no continuity of this professional development (TP) engagement at their own educational institutions. Additionally, such TPD activities have temporal and spatial constraints, which sometimes conflict with their routine teaching tasks. Most of the conventional PD programs do not accommodate these needs. In addition, such programs are costly, intermittently designed and implemented, and do not provide flexible and dynamic collaboration among English teachers.

On the other hand, virtual platforms such as MOOCs (Massive Open Online Courses) run by world-class universities offer a solution to those financial and practical constraints. Among other courses, these MOOCs provide TPD programs for teachers, which are collaborative, flexible, negotiable, and well-organized in nature. More crucially, MOOCs allow and stimulate an extensive (building professional connections with other teachers) and varied (sharing and exchanging ideas, views and opinions) platform for TPD. This environment definitely creates mutual professional learning and dynamic learning community of practice (CoP). Fasimpaur (2013, p. 17) further pinpoints that these MOOCs offer an authentic model of professional learning, "which allows for flexible and highly modularized content" so that participants are at liberty to choose what is most applicable to them. This virtual environment paves the way for teacher professional learning, which is practical, highly participatory, and flexible without temporal and spatial constraints. 
Coursera is a virtual platform established by Daphne Koller and Andrew $\mathrm{Ng}$ of Stanford University, which offers free online courses based on various fields of study run by different world-class universities. "Our technology enables the best professors to teach tens or hundreds of thousands of students. Through this we hope to give access to the world of top-class education that has so far been available only to a select few" (www.coursera.org). Established in 2012, Coursera now offers 431 courses from 85 partners (universities, colleges, and institution) with over 4,500,000 students. In 2015, Coursera provides 91 online courses (raised from 35 courses in 2013) focusing on teachers' professional development in various fields of study. Among those 91 courses, about 50 courses are tailored for English language teachers.

Each Coursera course has various durations of study, ranging from 4 weeks to 12 weeks and commonly requires 4-6 hour workload in a week. Each of them contains sequence of materials, which include:

a. course overview: covering the general description, goals, and objectives of the course.

b. syllabus: presenting the sequences of materials, quizzes, assignments, and peer assessment tasks throughout the study session.

c. readings: consisting of reading materials, which corresponds to the subject matter, in the form of book chapters, web articles, or published journal articles written by the instructors, which are freely readable.

d. peer assessment: comprising final assignments, which covers all taught materials.

e. grading and logistics: detailing the criteria of assessment, deadlines, and scoring rubric.

f. video modules: showing the professor's 10-15 minute presentation on the subject matter, equipped with subtitles and slides. The videos can be downloaded directly from the course page along with the subtitles and presentation slides.

g. discussion forum: facilitating questions, ideas, suggestions about the course content, particular technical issues, and thought sharing among participants, staff, and professors.

h. surveys: including pre-survey and post-survey reflecting on learning experience and attitudes towards the course.

Anchored in Garmston's (2003) effective PD programs elements, the effectiveness of Coursera features can be presented as follows. 
Table 1. The Features of Coursera Courses

\section{Elements of Effective PD Programs}

\begin{tabular}{|c|c|}
\hline Elements of Eifective PD Progra & Coursera Features \\
\hline $\begin{array}{l}\text { a. build competence in new tasks } \\
\text { or strategies }\end{array}$ & $\begin{array}{ll}\text { - } & \text { video modules } \\
\text { - } & \text { readings } \\
\text { - } & \text { discussion forums } \\
\text { - } & \text { quizzes }\end{array}$ \\
\hline b. create new structures & $\begin{array}{ll}- & \text { quizzes } \\
\text { - } & \text { assignments (essay) }\end{array}$ \\
\hline $\begin{array}{l}\text { c. try new roles in a safe environ- } \\
\text { ment }\end{array}$ & $\begin{array}{l}\text { - } \quad \text { support student group (through } \\
\text { social media like Facebook) } \\
\text { - } \quad \text { peer assessment }\end{array}$ \\
\hline $\begin{array}{l}\text { d. engage in discussions on be- } \\
\text { liefs and assumptions about is- } \\
\text { sues in relation to practice }\end{array}$ & 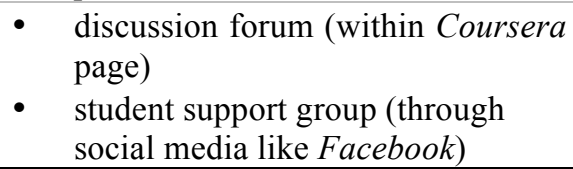 \\
\hline
\end{tabular}

Upon the completion of the course, each participant is entitled to receive a statement of accomplishment (with minimum $70 \%$ total grade) or statement of accomplishment with distinction for $>80 \%$ achievers. Alternatively, for participants who are willing to obtain a signed certificate, Coursera offers a Signature Track, which requires a payment for the certificate. This signature track is verified by the university and Coursera, and this track authenticates that the work is truly the participant's work, not someone else's.

Since 2013, Coursera is offering more professional development courses for teachers, started running in 2013 and 2014. Here are some of the courses:

a. Foundation of Teaching for Learning (8 courses) by Commonwealth Education Trust

b. Online Learning (4 courses) by New Teacher Center

c. Foundation of Virtual Instruction by University of California, Irvine

d. Effective Classroom Interactions: Supporting Young Children's Development by University of Virginia

e. Emerging Trends \& Technologies in the Virtual K-12 Classroom by UC Irvine

f. Coaching Teachers: Promoting Changes that Stick by Match Education

g. Common Core in Action: Literacy Across Content Areas by New Teacher Center

h. Engaging Students through Cooperative Learning by John Hopkins 


\section{University - School of Education \\ i. First Year Teaching by New Teacher Center}

The present article examines the extent to which a virtual course for a professional development program run by Coursera (coursera.org) benefits English teachers participating in the program. This empirical evidence accentuates the benefits of MOOCs and provides the basis for designing more meaningful and vibrant teacher professional learning and development. Findings of the present study can serve as the basis for designing online TPD programs, which consider factors mediating teachers' intentions to continue such programs in their institutional contexts. From a policy perspective, these findings also aim to "inform educational leaders of how to encourage teachers' continued use of e-learning for professional development" (Smith \& Sivo, 2012, p. 872).

\section{METHOD}

Drawing on Guskey's (2000) professional development (PD) evaluation, a survey case study was undertaken to examine teachers' attitudes towards the Coursera course. These attitudes were investigated based on five evaluative elements: (1) participant reaction, (2) participant professional learning, (3) participant use of new skills, (4) organizational culture, and (5) student learning outcomes. Thus, a question guiding the present study is "to what extent does the Coursera course for online TPD benefits participating teachers in relation to these elements?" In order to probe into this question, a survey questionnaire was adopted (see Appendix). The questionnaire was distributed to peer participants taking a Coursera course entitled Foundation of Teaching for Learning 1: Introduction. Their attitudes towards PD programs were carefully investigated. The survey consists of 15 items and was conducted online using a free survey tool called Survey Monkey. The link of the survey was posted on a discussion forum on the Coursera page and on the participants' Facebook group. The follow-up survey was undertaken in the last week of the course, during which time the participants already wrapped up the materials and assignments. Twenty-four informants from different countries (Russia, Italia, Brazil, Indonesia, USA, Turkey, and India) completed the survey questionnaire. These informants are teachers of 24-40 years old with 2-15 years of teaching experience. They come from a wide range of educational levels of teaching, from primary schools to university level, from public schools to non- 
profit educational organizations. Their previous PD programs include attending face-to-face seminars and conferences.

Means of each item are described as strongly positive (4 - 5), positive (3.5-3.9), neutral $(3.0-3.4)$, mildly negative (2.5-2.9), and strongly negative $(0-2.4)$. Thus, data were computed using a descriptive statistical analysis. All the data were then classified and tabulated to find out relevant findings. The findings were then selected based on five elements of Guskey's (2000) PD evaluation. The entire process of data analysis followed five steps as such: (1) create an Excel database, (2) code your data, (3) enter your data, (4) clean your data, and (5) analyze your data (see Leahy, 2004).

\section{FINDINGS AND DISCUSSION}

\section{Participant Reaction (Items 1-7)}

As indicated in Figure 2, most of the participants showed positive attitudes towards the content and nature of the TPD programs. They strongly opine that the online PD program is relevant to their field (Item 2) and that the required time allocated by the course developer suits their learning pace (Item 2). Further, they positively agree that the content of the PD program (clear objectives and good organization) find them gratifying (Items 1, 3, 5, 6). However, most of the participants does not take any stance that working together with their faculty colleagues will result better (Item 7); therefore, they do not involve their colleagues in designing teaching plans based on the online course.

This finding shows that there are three crucial elements of online TPD: relevancy to professional needs, sufficient learning time, and content. These elements can serve as the basis for developing TPD activities. This positive reflective attitude is necessary for ongoing and self-driven professional development (PD) in that professional learning and development cannot be forced. This suggests that teachers must "be open to engage in reflective dialogues, to take personal responsibility and not leave it to others" (Helleve, 2010, p. 9). Therefore, as pointed out earlier, effective TPD programs should accommodate teachers busy schedules, help them focus on integration with specific subject-matter content, and connect their professional learning to student learning (Jaquith et al., 2011; Ross, 2011). In addition to the usefulness of PD content for teachers, the program mediates the integration of social interactions and communities among 
teachers into the course system. In other words, needs, content, and time are important factors in determining whether virtual TPD activities work well and provide further impetus for best TPD programs, which involve (a) instruction in theory, (b) demonstration, (c) practice, (d) feedback, and (e) coaching.

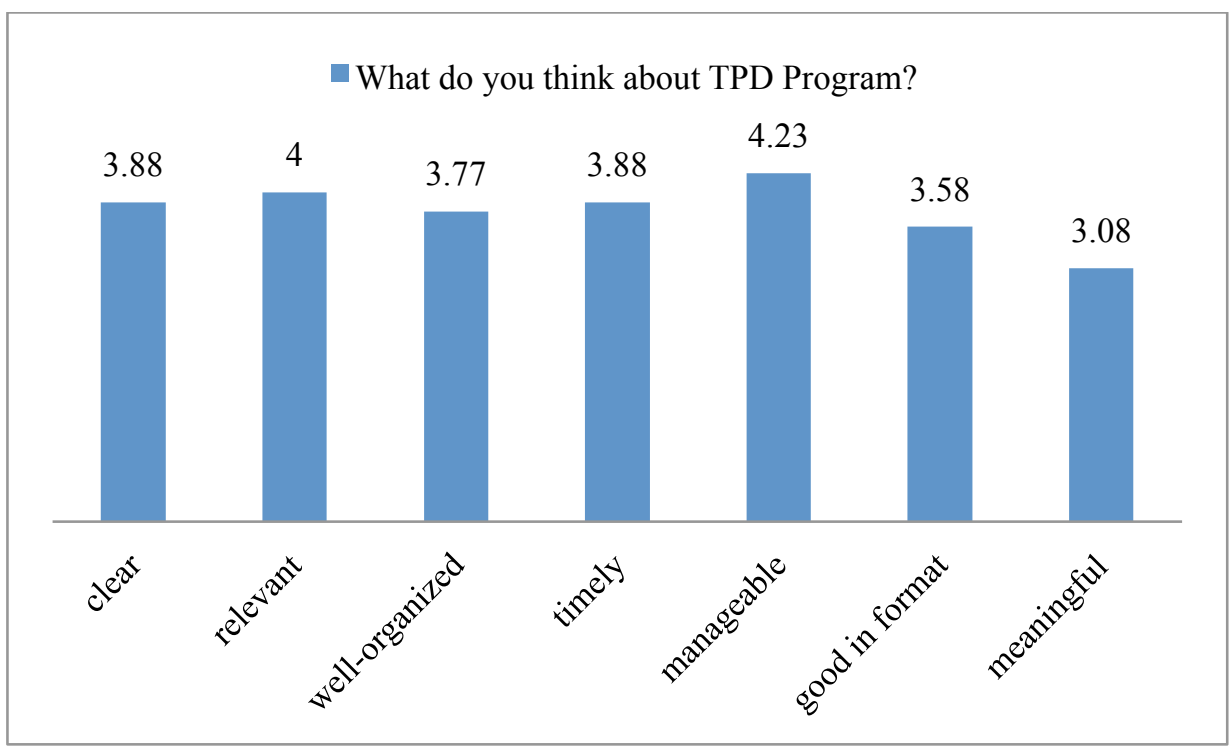

Figure 2: Participant Reaction (Items 1-7)

Time is also very important in TPD because as Scott (2010, p. 34) puts it,

It takes time for teachers to engage in TPD, which has financial implications in requiring the funding of substitute teachers to take their classes. Even though quick fixes are politically desirable, long term systematic TPD is more effective but does require the commitment of time for the processes to become embedded.

What Scott accentuates demonstrates that vibrant TPD is time-consuming. For this reason, professional needs and relevancy to their professional learning development become an essential component in continued TPD programs.

Another finding indicates that the participants do not see a need for collaborating with their colleagues in instructional design. This is because they do not build on collaborative culture in their own school or institutional context, 
which does not promote collaboration in a pedagogic design. For this reason, an electronic discussion board becomes an additional platform for teachers or educators to build collegial collaboration to address potential problems and solutions as well as collaborative reflections on what they have practiced so far. Anchored in this finding, MOOCs need to be accompanied with virtual discussion groups (e.g., Facebook).

\section{Participant Professional Learning (Items 8-11)}

In responding to their professional learning, most of the participants, as presented in Figure 3, positively voice that professional development program (TPD) helps them develop a better understanding of evidence-based practice for teaching (Item 8); integrate evidence-based practice materials into their pedagogic situation (Item 9); acquire the intended knowledge and skills to create their teaching plan (Item 10); and enhance their contributions to the school community (Item 11).

These findings show that the participants much value online TPD as a learning platform. This is relevant to the notion of learning community of practice (CoP). The online TPD program through MOOCs has fruitfully assisted teachers to enhance their practices because the program is tailored to teachers' specific needs, and accommodates teachers' busy schedules. This paves the way for a virtual platform, which affords English teachers an opportunity for professional learning. In turn, these "online teacher communities provide an opportunity to exchange ideas and experiences beyond their classroom walls" (Smith \& Sivo, 2012, p. 880). Thus, online TPD programs such as online courses should be tailored to develop teachers' full potential and make them feel empowered to engage in the programs.

These findings show that the participants much value online TPD as a learning platform. This is relevant to the notion of learning community of practice $(\mathrm{CoP})$. The online TPD program through MOOCs has fruitfully assisted teachers to enhance their practices because the program is tailored to teachers' specific needs, and accommodates teachers' busy schedules. This paves the way for a virtual platform, which affords English teachers an opportunity for professional learning. In turn, these "online teacher communities provide an opportunity to exchange ideas and experiences beyond their classroom walls" (Smith \& Sivo, 2012, p. 880). Thus, online TPD programs such as online courses should be tailored to develop teachers' full potential and 
make them feel empowered to engage in the programs.

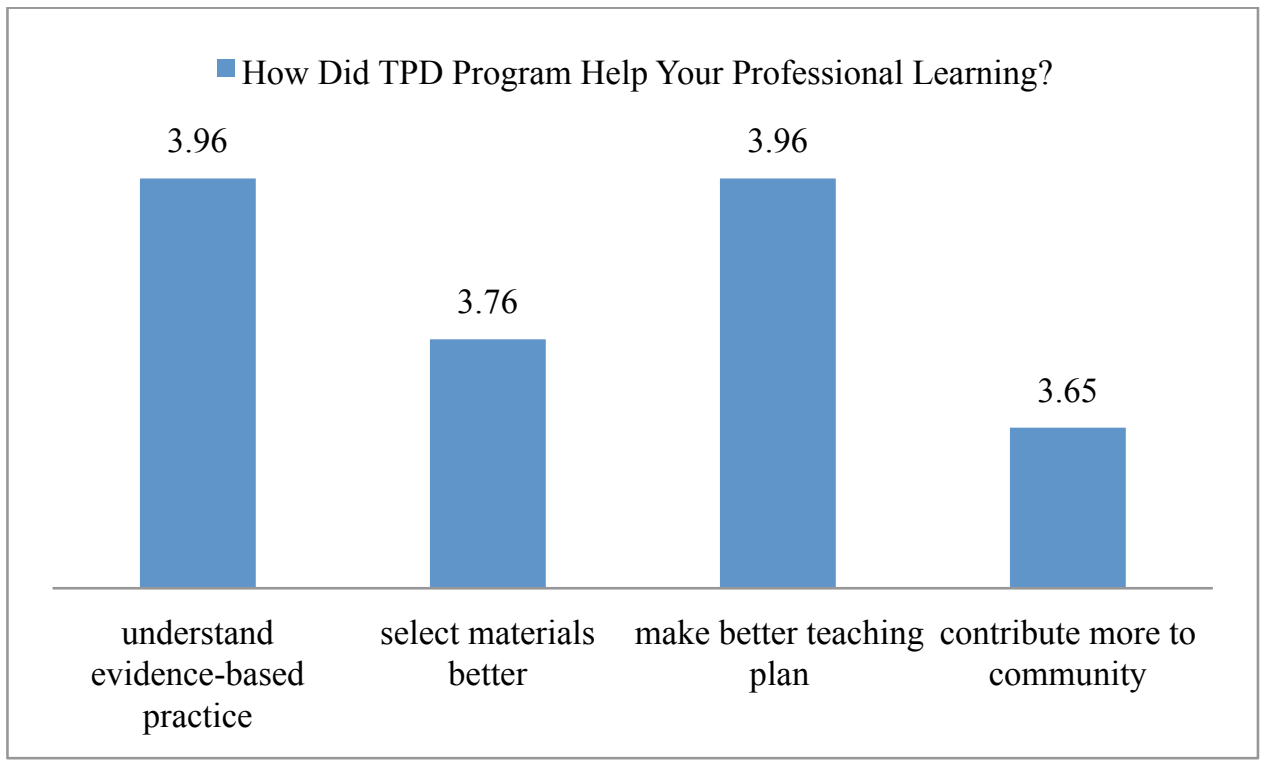

Figure 3: Participants' Professional Learning

\section{Participant Use of New Skills (Items 12-13)}

When asked about the use of new skills (see Figure 4), the participants strongly consider that they would put the assignment and plan from the course to support achievement in their school (Item 12), and they would share the knowledge gained in the course with various stakeholders in their school community (Item 13). This vested interest plays a crucial role in transforming TPD activities into teachers' actual teaching practice. Thus, the participants' commitment to making changes in instructional practice in response to the professional learning opportunities is a starting point for students' learning improvements. This can also be further impetus for classroom-embedded professional learning. This learning paves the way for both good and successful teaching. As emphasized by Fenstermacher and Richardson (2005):

By good teaching we mean that the content taught accords with disciplinary standards of adequacy and completeness, and that the methods employed are 
age appropriate, morally defensible, and undertaken with the intention of enhancing the learner's competence with respect to the content studied. By successful teaching we mean that the learner actually acquires, to some reasonable and acceptable level of proficiency, what the teacher is engaged in teaching. (p. 191)

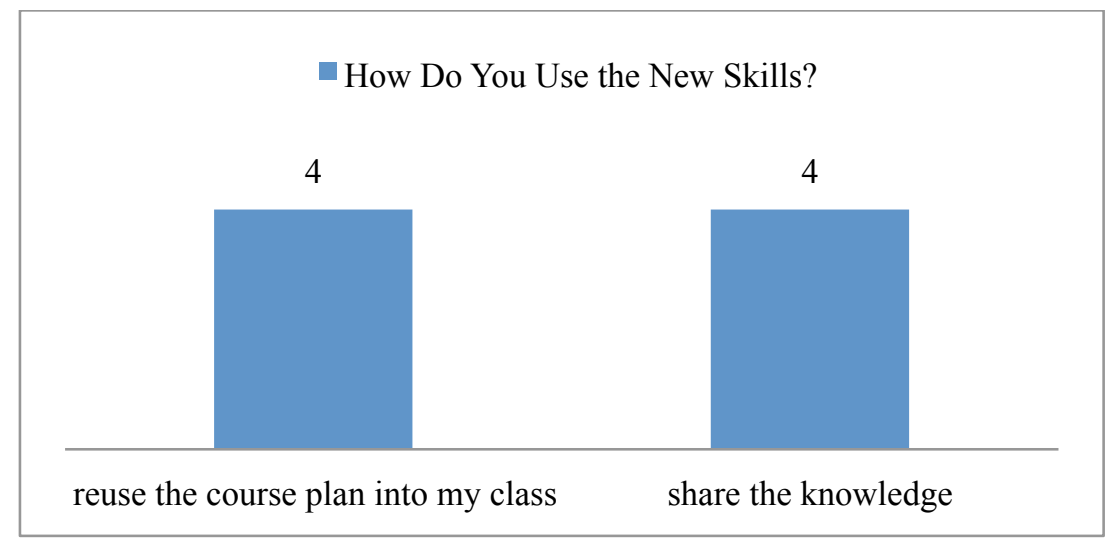

Figure 4: Participant Use of New Skills

This finding also emphasizes the conceptualization of "teacher professional learning as embedded in the classroom context and constructed through experience and practice in sustained iterative cycles of goal setting/planning, practicing, and reflecting" (Bruce, Esmonde, Ross, Dookie, \& Beatty, 2010, p. 1599). In other words, an online TPD program makes possible the transition from the professional development course to the classroom.

\section{Organizational Culture (Item 14)}

As shown in Figure 5, in relation to organizational or institutional culture, the participants lament that follow-up TPD plans from the course were not supported by their institutions. This means that there is no support system from administrators or educational leaders to help the teachers develop their professionalism through locally tailored online courses. This empirical evidence calls for a need "for policy and decision makers to increase their understandings of the theory about effective TPD and how this should be implemented. They should also understand how this 'theory-practice' disparity influences teachers' 
behaviors and motivations, and organizational reforms and culture" (Scott, 2010, p. 28). Educational leaders should be fully aware that "online learning community for TPD holds promise as the most effective way for teacher professional development programs to provide participants with continuing support, combining the potential for rigorous content, adequate assessment, and sustainable community" (Liu, 2012, p. 702). Healthy and supportive institutional culture contributes energy to building and sustaining TPD programs whose ultimate goal is to enhance teaching and learning.

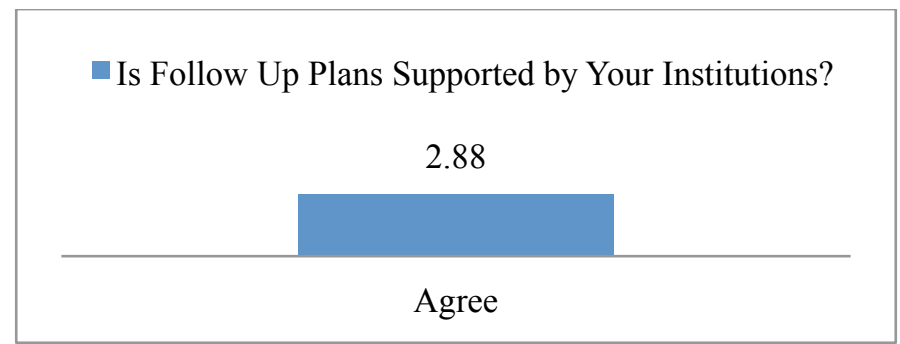

Figure 5: Means of Organizational Culture

Thus, sound leadership and empowerment of teachers are crucial dimensions of continued TPD programs as far as supportive organizational culture is concerned. More crucially, institutional leaders must take cognizance of "supportive and shared leadership, shared values and vision, collective learning and application of learning, supportive conditions (physical, human capacities), and shared practice" (Hord, 1998, as cited in McConnell, Parker, Eberhardt, Koehler, \& Lundeberg, 2013, p. 269). They also need to formulate institutional policy on the deployment of online TPD programs (e.g., designing locally-tailored MOOCs) in order to meet PD needs that weight flexibility, sustainability, and rigor in TPD.

\section{Student Learning Outcomes (Item 15)}

The means of student learning outcomes (see Figure 6) denote that the participants strongly opine that the course has a significant impact on their teaching; thereby positively affecting students ${ }^{6}$ achievements. This finding resonates with Dinardo's (2010) and Peters' (2013) findings that professional 
development (PD) programs for teachers empirically support demonstrable changes in student learning and increase students' achievements. This empirical evidence suggests that TPD activities should attempt to enhance quality of students' learning and in turn increase their academic or school attainment. Guskey (2000) maintains that "one constant finding in the research literature is that notable improvements in education almost never take place in the absence of professional development ... it is an absolutely necessary ingredient in all educational improvement efforts" (p. 4). Thus, it is indispensable that teachers and faculty members engage in meaningful and vibrant professional development "to update and expand their skills and content knowledge" (Smith \& Sivo, 2012, p. 871).

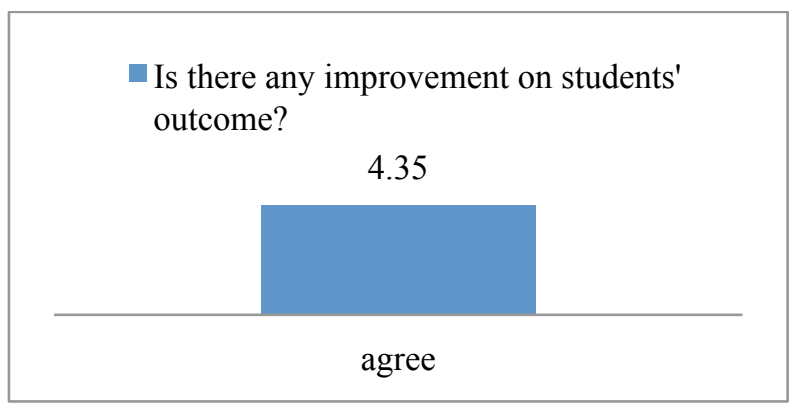

Figure 6: Student Learning Outcomes

Thus, both relevant TPD programs and student learning attainment are inextricably intertwined because teachers are actual agents of innovation and change in their own teaching practices. University and school authorities have to become fully aware that TPD programs should be tailored for such innovation and change. Therefore, both teachers and policy makers should build mission and vision in relation to developing and sustaining TPD programs, which impact on both teacher professional learning and student learning inasmuch as both are actual actors of language curriculum enactment and evaluation.

\section{CONCLUSIONS AND SUGGESTIONS}

This article has reported on how a virtual course benefits English teachers' professional development. Drawing on the findings, the participants 
commonly have positive attitudes towards the nature and content of the course and their independent professional learning. They also positively feel that the course exerts influence on their teaching philosophy and practice. However, they do not think positively about institutional and collegial support of their online PD programs. Despite this problem, the participants positively believe that online PD programs have positive impacts on their pedagogic practices and students' achievements. This suggests that administrators or policy makers need to realize that their teaching staffs deserve the rights to develop professionally because teachers are life-long learners. Their professional learning is also part of their professional identities as teachers. Being professional involves life-long learning, which requires hours of learning, reflecting, reproducing, delivering, investigating, and reporting. It is about time that English teachers should be both active learners in their professional development programs and productive researchers in their fields.

In spite of useful findings presented in this article, we recognize that the present study does not longitudinally examine the participants' attitudes towards their ODP through MOOCs in relation to (a) participant reaction, (b) participant professional learning, (c) participant use of new skills, (d) organizational culture, and (e) student learning outcomes. For this reason, further studies should look into such issues using an ethnographic narrative approach. This will capture detailed and unique stories of English teachers engaging in virtual TPD activities.

Future studies may investigate how MOOCs mediate continued online TPD activities coupled with the intensive use of social media such as Facebook, bulletin board discussion groups, course management software, wikis, blogs, or video conferencing software such as Skype. There is also a growing need for further investigation into the impact of online professional development communities (e.g., locally-tailored MOOCs) particularly on promoting pedagogic practice and student learning performance. All of these examples support collaborative professional learning among English teachers without any geographic and temporal barriers.

\section{Acknowledgement}

I offer my highest appreciation to Mr Handoyo Widodo, Ph.D for his kind input and comments on this manuscript. 


\section{REFERENCES}

Bruce, C. D., Esmonde, I., Ross, J., Dookie, L., \& Beatty, R. (2010). The effects of sustained classroom-embedded teacher professional learning on teacher efficacy and related student achievement. Teaching and Teacher Education, 26(8), 1598-1608.

Dinardo, L. M (2010). The impact of professional learning communities on student achievement. Retrieved from ProQuest Dissertations and Theses database. (UMI No. 3404341)

Fasimpaur, K. (2013). Massive and open: massive open online courses (MOOCS), which are already changing the face of higher education, are starting to create new opportunities in K-12 professional development. Learning \& Leading with Technology, 40(6), 12-17.

Fenstermacher, G. D., \& Richardson, V. (2005). On making determinations of quality in teaching. Teachers College Record, 107, 186-213.

Garmston, R. J. (2003). Group wise. Journal of Staff Development, 24(4), 6566.

Guskey, T. R. (2000). Evaluating professional development. Thousand Oaks, CA: Corwin Press.

Guskey, T. R. (2002). Professional development and teacher change. Teachers and Teaching: Theory and Practice, 8(3), 381-391.

Helleve, I. (2010). Theoretical foundations of teachers' professional development. In J. O. Lindberg \& A. D. Olofson (Eds.), Online learning communities and teacher professional development: Methods for improved education delivery (pp. 1-19). Hershey, PA: IGI Global.

Jaquith, A., Mindich, D., Wei, R. C., \& Darling-Hammond, L. (2010). Teacher professional learning in the United States: Case studies of state policies and strategies: A technical report. Oxford, OH: Learning Forward.

Leahy, J. (2004). Using Excel for analyzing survey questionnaires. Retrieved from https://learningstore.uwex.edu/assets/pdfs/G3658-14.pdf

Liu, K. Y. (2012). A design framework for online teacher professional development communities. Asia Pacific Education Review, 13(4), 701-711. 
McConnell, T. J., Parker, J. M., Eberhardt, J., Koehler, M. J., \& Lundeberg, M. A. (2013). Virtual professional learning communities: Teachers' perceptions of virtual versus face-to-face professional development. Journal of Science Education and Technology, 22(3), 267-277.

Peters, E. (2013). Professional learning communities: Teachers' perceptions and student achievement. Retrieved from ProQuest Dissertations and Theses database. (UMI No. 3558298)

Ross, J. D. (2011). Online professional development: Design, deliver, succeed! Los Angeles, CA: Corwin Press.

Scott, S. (2010). The theory and practice divide in relation to teacher professional development. In J. O. Lindberg \& A. D. Olofson (Eds.), Online learning communities and teacher professional development: Methods for improved education delivery (pp. 20-40). Hershey, PA: IGI Global.

Smith, J. A., \& Sivo, S. A. (2012). Predicting continued use of online teacher professional development and the influence of social presence and sociability. British Journal of Educational Technology, 43(6), 871-882. 
244 TEFLIN Journal, Volume 26, Number 2, July 2015

\section{Appendix 1: Questionnaire}

1. The goals and objectives of the professional program were clear

$\begin{array}{ccccc}\mathrm{O} & \mathrm{O} & \mathrm{O} & \mathrm{O} & \mathrm{O} \\ \text { strongly } & \text { disagree } & \text { undecided } & \text { agree } & \begin{array}{c}\text { strongly } \\ \text { agree }\end{array}\end{array}$

2. The professional development program content was relevant and consistent with overall objectives

$\begin{array}{ccccc}\mathrm{O} & \mathrm{O} & \mathrm{O} & \mathrm{O} & \mathrm{O} \\ \text { strongly } & \text { disagree } & \text { undecided } & \text { agree } & \begin{array}{c}\text { strongly } \\ \text { agree }\end{array}\end{array}$

3. The professional program was well organized

$\begin{array}{ccccc}\mathrm{O} & \mathrm{O} & \mathrm{O} & \mathrm{O} & \mathrm{O} \\ \begin{array}{c}\text { strongly } \\ \text { disagree }\end{array} & \text { disagree } & \text { undecided } & \text { agree } & \begin{array}{c}\text { strongly } \\ \text { agree }\end{array}\end{array}$

4. The time required for professional development was appropriate

\begin{tabular}{|c|c|c|c|}
\hline $\begin{array}{c}\mathrm{O} \\
\text { trongly } \\
\text { lisagree }\end{array}$ & $\begin{array}{c}\mathrm{O} \\
\text { disagree }\end{array}$ & $\begin{array}{c}\mathrm{O} \\
\text { undecided }\end{array}$ & $\begin{array}{c}\mathrm{O} \\
\text { agree }\end{array}$ \\
\hline
\end{tabular}

5. Setting my own schedule for involvement in professional development worked well for me

$\begin{array}{ccccc}\mathrm{O} & \mathrm{O} & \mathrm{O} & \mathrm{O} & \mathrm{O} \\ \text { strongly } & \text { disagree } & \text { undecided } & \text { agree } & \text { strongly } \\ \text { disagree } & & & & \text { agree }\end{array}$


6. The Foundation of Teaching for Learning 1 (Introduction) support plan was appropriate in length and format

$\begin{array}{ccccc}\text { O } & \mathrm{O} & \mathrm{O} & \mathrm{O} & \mathrm{O} \\ \text { strongly } & \text { disagree } & \text { undecided } & \text { agree } & \begin{array}{c}\text { strongly } \\ \text { disagree }\end{array} \\ & & & & \end{array}$

7. Working with other faculty at my institution/ school helped me create a more meaningful plan

$\begin{array}{ccccc}\mathrm{O} & \mathrm{O} & \mathrm{O} & \mathrm{O} & \mathrm{O} \\ \text { strongly } & \text { disagree } & \text { undecided } & \text { agree } & \begin{array}{c}\text { strongly } \\ \text { disagree }\end{array} \\ & & & & \text { agree }\end{array}$

8. The professional development program helped me develop a greater understanding of evidence-based practice for teaching.

\begin{tabular}{|c|c|c|c|c|}
\hline $\begin{array}{c}\mathrm{O} \\
\text { strongly } \\
\text { disagree }\end{array}$ & $\begin{array}{c}\mathrm{O} \\
\text { disagree }\end{array}$ & $\begin{array}{c}\mathrm{O} \\
\text { undecided }\end{array}$ & $\begin{array}{c}\mathrm{O} \\
\text { agree }\end{array}$ & $\begin{array}{c}\mathrm{O} \\
\text { strongly } \\
\text { agree }\end{array}$ \\
\hline
\end{tabular}

9. The professional development activities helped me integrate evidence-based practice material into my situation

$\begin{array}{ccccc}\mathrm{O} & \mathrm{O} & \mathrm{O} & \mathrm{O} & \mathrm{O} \\ \begin{array}{c}\text { strongly } \\ \text { disagree }\end{array} & \text { disagree } & \text { undecided } & \text { agree } & \begin{array}{c}\text { strongly } \\ \text { agree }\end{array}\end{array}$

10. This professional development program helped me acquire the intended knowledge and skills to create my teaching plan

$\begin{array}{ccccc}\mathrm{O} & \mathrm{O} & \mathrm{O} & \mathrm{O} & \mathrm{O} \\ \text { strongly } & \text { disagree } & \text { undecided } & \text { agree } & \text { strongly } \\ \text { disagree } & & & & \text { agree }\end{array}$


11. The professional development program enhanced my contributions to the school community

$\begin{array}{ccccc}\text { O } & \mathrm{O} & \mathrm{O} & \mathrm{O} & \mathrm{O} \\ \text { strongly } & \text { disagree } & \text { undecided } & \text { agree } & \begin{array}{c}\text { strongly } \\ \text { disagree }\end{array} \\ & & & & \text { agree }\end{array}$

12. I will put the assignment and plan in my course into use to support achievement in my school

\begin{tabular}{|c|c|c|c|c|}
\hline $\begin{array}{c}\mathrm{O} \\
\text { strongly } \\
\text { disagree }\end{array}$ & $\begin{array}{c}\mathrm{O} \\
\text { disagree }\end{array}$ & $\begin{array}{c}\mathrm{O} \\
\text { undecided }\end{array}$ & $\begin{array}{c}\mathrm{O} \\
\text { agree }\end{array}$ & $\begin{array}{c}\text { O } \\
\text { strongly } \\
\text { agree }\end{array}$ \\
\hline
\end{tabular}

13. I will communicate the knowledge I gained in this course to various stakeholders in my school community

\begin{tabular}{|c|c|c|c|}
\hline $\begin{array}{c}\mathrm{O} \\
\text { strongly } \\
\text { disagree }\end{array}$ & $\begin{array}{c}\mathrm{O} \\
\text { disagree }\end{array}$ & $\begin{array}{c}\mathrm{O} \\
\text { undecided }\end{array}$ & $\begin{array}{c}\mathrm{O} \\
\text { agree }\end{array}$ \\
\hline
\end{tabular}

14. Creating follow up plan from this course was supported by my campus/ institutions

\begin{tabular}{|c|c|c|c|}
\hline $\begin{array}{l}\mathrm{O} \\
\text { rongly }\end{array}$ & $\begin{array}{c}\mathrm{O} \\
\text { disagree }\end{array}$ & $\begin{array}{c}\mathrm{O} \\
\text { undecided }\end{array}$ & $\begin{array}{c}\mathrm{O} \\
\text { agree }\end{array}$ \\
\hline
\end{tabular}

15. I believe my new learning is likely to increase my student performance

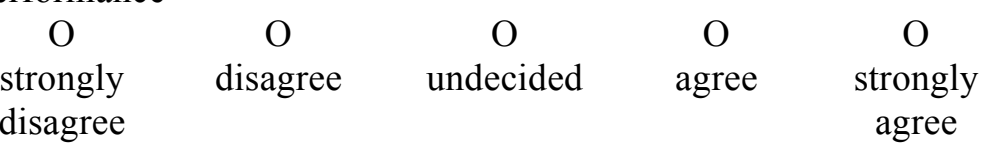

